\title{
Message of the President of the Brazilian League of Epilepsy
}

E sta breve mensagem inicia o biênio 2006-2008 da nova diretoria da Liga Brasileira de Epilepsia.

Em nome dos Drs. Carlos Guerreiro (Secretário), Luiz Eduardo Betting (Tesoureiro) e Kette Dualibi Ramos Valente (Secretária Executiva), quero agradecer aos colegas da Liga pelo voto de confiança para que possamos representá-los neste biênio.

Vamos dar prosseguimento aos vários projetos iniciados pela diretoria anterior, bem como trabalhar para uma maior representatividade da Liga junto aos órgãos oficiais representativos da comunidade científica e médica brasileira, bem como trabalhar em conjunto com as associações de pacientes com o objetivo de melhorar a qualidade de vida das pessoas com epilepsia neste país.

Contamos com a ajuda de todos nesta empreitada.

Fernando Cendes

Presidente da LBE 2006-2008 